Victor, V., Thoppan, J. J., Fekete-Farkas, M., \& Grabara, J. (2019). Pricing strategies in the era of digitalisation and the perceived shift in consumer behaviour of youth in Poland. Journal of International Studies, 12(3), 74-91. doi:10.14254/2071-8330.2019/12-3/7

\title{
Pricing strategies in the era of digitalisation and the perceived shift in consumer behaviour of youth in Poland
}

\author{
Vijay Victor \\ Doctoral School of Management and Business Administration, \\ Szent Istvan University, Hungary \\ Victor.Vijay@phd.uni-szie.hu \\ Saintgits Institute of Management, Kottukulam Hills, Pathamuttom \\ India \\ Vijay.Victor@Saintgits.org \\ Jose Joy Thoppan \\ Saintgits Institute of Management, Kottukulam Hills, Pathamuttom \\ India \\ jose.joy@saintgits.org
}

\section{Maria Fekete-Farkas}

Faculty of Economic and Social Sciences, Szent Istvan University,

Hungary

Farkasne.Fekete.Maria@gtk.szie.hu

\section{Janusz Grabara}

The Management Faculty,

Crestochowa University of Technology,

Poland

janusz@grabara.eu

Abstract. The advent of industry 4.0 along with the spread of Information and Communication Technology has brought about many pivotal changes in the ECommerce segment. Technology driven pricing strategies like dynamic pricing has become very common across different industries all over the world. Today, online pricing has evolved into a very efficient and sophisticated pricing strategy where product prices are personalised and tailored to the last conceivable individual buying unit possessing similar characteristics. This study examines various traits exhibited by online consumers in a dynamic pricing environment and figure out the reasons for the display of strategic purchase behaviour by the consumers in response to the dynamic pricing strategy adopted by the sellers. The study was conducted among the Polish millennials as Poland has the median online market size and growth rate among the Central and Eastern European

Received: January, 2019 1st Revision: April, 2019

Accepted: September, 2019

DOI:

10.14254/20718330.2019/12-3/7 
Countries. A PLS based structural equation modelling used in the study reveals that many factors including fair price perception of consumers, social influence, awareness about the pricing strategy and shopping experience influence the motivations for consumers to display a strategic purchase behaviour.

Keywords: dynamic pricing, e-commerce, strategic purchase behaviour, revenue management, PLS SEM

JEL Classification: D820, D910, D810

\section{INTRODUCTION}

Pricing is one of the four 'P's (product, place, promotion, price) in marketing research which plays a crucial role in determining the profitability of a seller. Pricing strategy plays a key role in maintaining a sustainable revenue management in any business arena (Schlosser \& Boisser, 2018; Greenstein-Messica \& Rokach, 2018). The advent of globalisation and the resulting transmission of the crisis from a single economy to the global marketplace have brought forth several problems to multinational companies. These issues have forced the multinationals to frame various strategic business models and pricing techniques to maintain a competitive edge in a cut throat business environment. However, revenue optimisation through pricing strategies which retains a loyal consumer base is not an easy task to execute. Finding the right price for a product at a time which maximises the firm's profitability and at the same time doesn't hurt the consumer price perceptions is a very complicated task. It is in this regard, revenue management techniques are gaining momentum internationally. Revenue management aims at selling the right product to the right customer at the right price, time and place ensuring the optimal usage and minimum wastage of available resources which in turn maximises the revenue of a firm (Cross, 1997) One of the most common and successfully practiced revenue management techniques in the Electronic Commerce segment by many multinationals including Amazon, Walmart etc. is the dynamic pricing strategy in which the price of a product is determined in accordance with its corresponding market demand and supply (Han et al., 2018).

Dynamic pricing has lately thrived as a highly effective operations research tool which has been widely used in product pricing. Gönsch, Klein, \& Steinhardt (2009) define dynamic pricing as a pricing strategy where the seller sets a non-negotiable price that changes dynamically over time. Sahay (2007) observes that various industries like apparels, electronics, personal services telecommunication, electricity, travel and leisure, online retail and even second hand product sales have successfully adopted Dynamic Pricing techniques to improve their top line and bottom line growth. The internet penetration had reshaped the pricing landscape and fragmenting the customer segmentation to the last unit (Shiller, 2013). Dong, Kouvelis \& Tian (2009) shows that dynamic pricing works optimally only when inventory is scarce, and it is also constrained by varied customer segments and quality of in-stock variates.

With the advent of big data analytics, this pricing strategy has gone a step further in which price is tailor made for each person or for a group of people who represent similar characteristics such as similar taste and preferences, similar income range etc. This is popularly known as personalised pricing strategy which helps sellers to squeeze consumer surplus to the maximum possible extent (Townley et al., 2017; Omelchenko et al., 2016). The sellers have reliable information even regarding the perceived ability to pay of a consumer which aids them to group people and employ the price discrimination strategy with more confidence. This has become possible with the availability of massive amounts of data and the availability of technology to descry useful insights from them (OECD, 2018). However, this strategy has not become widespread yet. 
The spread of Information and Communication Technology (ICT) has been advantageous to the consumers as well. Nowadays consumers are well aware of the different pricing techniques employed by the firms (Zhidebekkyzy et al., 2019; Slintak, 2019). The term "Strategic Consumer" is commonly used in the literature these days to describe a rational and forward-looking consumer who makes inter temporal purchase decisions to maximise own utility (Papanastasiou \& Savva, 2016). In simple words, strategic consumers make purchase decisions based on the available information and might delay their purchase if it doesn't maximise their utility. Revenue optimisation in the presence of strategic consumers can be a big problem for the firms and have been acknowledged by many previous studies (Aviv \& Pazgal, 2008; Besbes \& Lobel, 2015; Ryzin \& Liu, 2008; Vdovtsova, 2008) Although the employment of sophisticated pricing techniques like dynamic pricing strategy was expected to neutralize the effect of the consumers making strategic decisions, the consumers tend to make even better purchase decisions which hurt the profit of sellers as they have access to price history and other information about the products sold online. The presence of strategic consumer in the market can be detrimental to a wide range of daily operational decisions of firms. The decisions regarding inventories, stocking quantities, timing of new product launches etc cannot be effective if the consumers display a strategic purchase behaviour (Aviv \& Pazgal, 2008; Ryzin \& Liu, 2008). Hence it is very crucial for the firms to figure out the factors which drive the consumers to make strategic purchase decisions so that they can deploy effective counter measures and frame better strategies to gain a competitive advantage over other firms without losing their customer base.

Several previous studies (Haws \& Bearden, 2006; Dai, 2010; Stefko et al., 2011; Le \& Liaw, 2017; Victor et al., 2018a) examined the changes in consumer behaviour in an online dynamic pricing context. This study proposes to extend the results by taking into account of the behaviour of consumers in the E-Commerce segment of one of the fastest growing Central European Countries. Poland being the sixth most populous country in EU with a population around 38 million people offer plenty of opportunities for firms in the online business arena (Bredzel-Skowera \& Turek, 2015). The Polish population is increasingly using the possibilities of E-commerce and the total sales was estimated as 9.3 billion Euro at the end of 2018. The internet penetration as a percentage of the total population in Poland was $77 \%$ in 2018 (eCommerceEurope, 2019) and 64\% among the total users who use internet on a daily basis (Statista, 2019) while 61\% of the internet users shop on the net with the e-GDP contributing about $2.5 \%$ of the economic and doubling every four years (eCommerce-Europe, 2019). These statistics show a promising future for the E-Commerce sector in Poland.

It is worthwhile to mention a quote made by Adams (1965) on equity to explain the relevance of this study. Adams stated, "the presence of inequity will motivate the perceiver to achieve equity or to reduce inequity; and the strength of motivation to do so will vary directly with the perceived magnitude of inequity experienced" (P. 283).

Interpreting the statement in the context of dynamic pricing in E-Commerce has implications that the consumers do have the tendency to resort to measures which will compensate for the perceived loss due to the price differences and their motivation to do so depends on the magnitude of the price difference with the reference price which the consumer perceived as fair. This study conducted among the millennials in Poland, attempt to identify, analyse and compare the significance of factors motivating the consumers in the E-Commerce sector to display a strategic purchase behaviour in a dynamic pricing environment through a PLS based Structural Equation Modelling.

\section{RESEARCH BACKGROUND AND THEORY BUILDING}

This section gives the theoretical background of the dynamic pricing strategy and the choice of constructs for the study as well as hypotheses development based on the previous literature. 
Among the various pricing strategies, dynamic pricing has become a commonly practiced price discrimination strategy used by sellers in the E-Commerce to maximize profits by charging different prices for very similar or essentially the same products or services in accordance with the amount of money the customer is willing to pay (Haws \& Bearden, 2006). Amazon's first experimentation with the dynamic pricing strategy in 2000 was not very well perceived by the buyers though. The practice of dynamic pricing could be traced back to the 1970's when the airline industry started actively experimenting with and manipulating the technique to maximise their revenue.

The Cambridge dictionary defines dynamic pricing as the 'way of setting the price for a product or service in which the price changes according to how much demand there is for it at a particular time'. This is not an entirely novel concept. As professor Paul Krugman rightly denoted, "dynamic pricing is merely a new version of the age-old practice of price discrimination" (Krugman, 2000). Yet, today's price discrimination differs in the sense that current technology has made dynamic pricing not only widely possible, but also commercially viable. The current technological progress has caused a paradigm shift in price determination by taking pricing strategy to a whole new level. Changing prices minute by minute and sometimes tailoring them for a specific individual by processing information about what is known about consumer's income, spending habits, tastes etc. is being practically employed worldwide (Victor and Bhaskar, 2017). Dynamic pricing has become a norm in the E-commerce sector as the menu cost in the internet market is minimal. The cost of changing prices in internet marketing is negligible and online sellers can easily experiment with different prices to obtain a larger profit margin.

Time based pricing is very prevalent across industries. According to Kambil, Wilson and Agrawal (2002), in fashion and electronics the customer is willing to pay a premium for being the first to acquire a product whereas in travel and leisure the customer is willing to pay a premium to keep his options open till the last minute. This has led to the development of two common pricing strategy, namely, peak load pricing and clearance pricing.

Dinev and Hart's (2006) found the three factors that were strongly related to the willingness of an individual to provide personal information were privacy concerns, trust, and personal interest. The Ajzen's (1991) Theory of Planned Behavior is the foundation on which most of the work on ethical consumer behavior models are based. Chatzidakis et al. (2007) suggest that personal values, norms and internal ethics are the primary drivers of an ethical customer's purchase. However, multiple studies (e.g. Arvola et al., 2008; Shaw \& Shui, 2002; Vermeir \& Verbeke, 2008) suggests that though ethical consumerism has become an important consideration in framing a consumer's intent, it is not translated into actual purchase decision. Predictive models (Ouellette \& Wood, 1998) identify habits are an important factor, where a consumer's habitual responses override his intentions. The price of the product, ease of acquisition, familiarity with the brand and quality of the product are perceived to the more important decision criteria, while other factors are only considered by only a minority of consumers (Carrigan \& Attalla, 2001; Weatherell et al., 2003). Perishability is another important factor that is required for dynamic pricing in various degrees across different industries like hotel, leisure, airlines, electricity and fashion (Lovelock, 1984; Vovk \& Vovk, 2017). These studies show that there is a scope for dynamic pricing as different consumers value the same product differently. However, dynamic pricing may not be seen from a very favorable light by the customers unless he has a perceived value sufficient to bridge the cost differential.

Andreff \& Szymanski (2009) show that according to neoclassical demand theory, a consumer, constrained by his budget, will choose a consumption bundle that maximizes his utility based on his preferences. Thus, the price is negatively correlated with the demanded quantity. Sahay (2007) observes that consumers in general are resistant to dynamic pricing if they are based on their past individual behavior or their ability to pay but are more accommodative where they are involved in the pricing process. It can be observed that auctions and group buys where price discrimination is inevitable, have a higher degree of 
acceptance because customers feel more under control. Tellis (1986) says that dynamic pricing should be undiscernible, random and infrequent to the uninformed customer, that he usually purchases at higher prices. Firms should try to maximize the number of uninformed at the higher end of the price range and minimize the number of uninformed at the lower end of the its price range compared to the competitor's low price, thus improving sales volume and value.

It is apparent from the existing literature that the consumers are sensitive to price discrimination of any kind (Dai, 2010; Xia et al., 2004; Bolton et al., 2003). There is a high probability that the consumers may display a strategic purchase behaviour after encountering a price discriminatory experience from an online seller (European Commission, 2018; Victor et al., 2018b). To capture the possibilities of consumers tending to display strategic purchase behaviour, two constructs were added in the study. The construct 'intentions to display a strategic purchase behaviour' was adapted from the unified theory of acceptance and use of technology model (utaut) model developed by Venkatesh et al., 2003 and modified to fit the study purposes. The construct is used to explain the intentions of a consumer to wait for price mark downs in a personalized dynamic pricing context based on the influence of various other constructs under study. Since intentions do not always necessarily lead to actual decisions (Perugini \& Bagozzi, 2004), another construct was used to measure the actual desires of consumers to display a strategic purchase behaviour which was adopted from the previous research (Victor et al., 2018a). Strategic purchase behaviour in this context means the consumers' intentions to track product prices online and wait for price markdowns to make a purchase.

Maxwell (1995) defined the concept of price fairness from a social and economic perspective. From the economic perspective, a price is considered as fair if it maximises the utility and covers the cost of benefits that a consumer receives. A price is socially accepted as a fair price when it is presupposed as a tool that operates in accordance with the rules and regulations of the society. The introduction of novel pricing strategies like dynamic pricing have already hurt the consumer fair price perceptions. Buyers pay different prices for essentially the same product. The extreme changes in prices as in airline industry where prices sometimes double in one day are still practiced. The price variation of a backpack available on different Amazon websites from 1st July 2019 to 16th September 2019 is given in figure 1. The data was collected from an online price tracking software named Keepa.

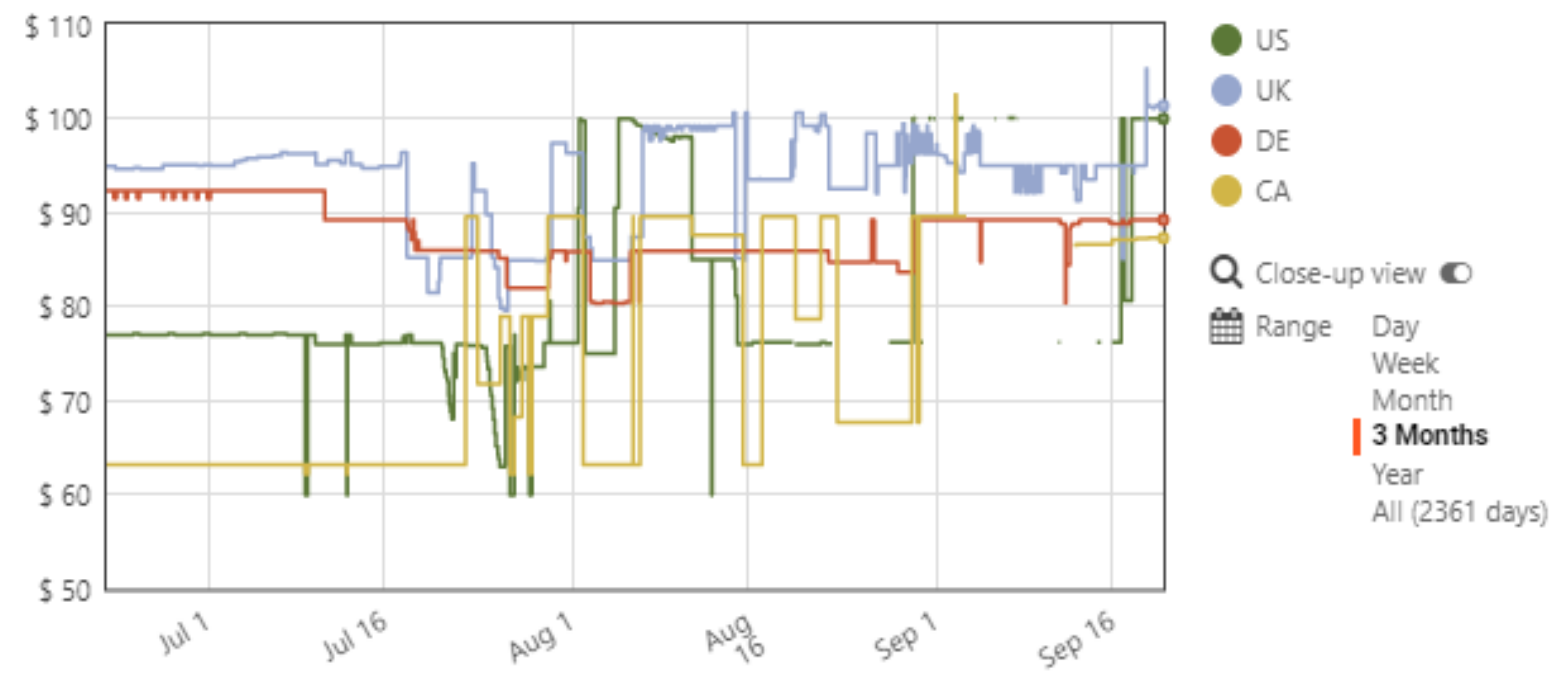

Figure 1. Real price fluctuation of the selected product across Amazon websites Source: Keepa (2019) 
Figure 1 shows that the price varies in different magnitude and proximity in different countries. Many previous studies (Dai, 2010; Xia et al., 2004; Bolton et al., 2003) have shown that the fair price perception of consumers is sensitive, and it might affect their purchase satisfaction which can lead to cognitive dissonance. The latest price of the selected product on different amazon websites as available on Keepa on 19th September 2019 is given in Table 1.

Table 1

Price variation of the selected product across Amazon websites

\begin{tabular}{|l|c|}
\hline Amazon sites & Price \\
\hline Amazon.com & $\$ 99.94$ \\
\hline Amazon.ca & $\$ 87.27$ \\
\hline Amazon.co.uk & $\$ 101.33$ \\
\hline Amazon.de & $\$ 89.20$ \\
\hline
\end{tabular}

Source: Keepa, (2019)

This study hypothesises that fair price perception has a direct influence on the strategic purchase behaviour and purchase satisfaction. Specific hypotheses to test fair price perception in this study are as follows:

H1. Fair Price Perceptions of consumers is inversely related to the motivation to display a strategic purchase Behaviour.

H1a. Fair Price Perceptions of consumers is inversely related to the Intentions to display a strategic purchase behaviour.

H1b. Fair Price Perceptions of consumer is positively related to the overall purchase satisfaction.

Hawthorne and Stanley (2008) explains the relationship between knowledge and action. There exists a connection between knowledge and action which is backed by reasoning. The concept of knowledge is therefore intertwined with the rationality of action to a great extent. Further, Bandura (1980) also shows how appropriate response patterns are formed based on the awareness of a person about things. In an online market environment, there is a high chance that the awareness about the pricing strategy employed by the seller will persuade the consumers to take advantage of it. One simple example to mention is the airline industry. The consumers often wait and book the tickets at the lowest prices possible under the given conditions (Kannan, 2001). This is possible in an E-Commerce scenario too if the consumers have sufficient information about the pricing strategies. With the ICT being widespread, consumers have access to the price volatility of products and many web based applications are freely available to monitor the price changes (Victor et al., 2018b) Hence we hypothesise;

H2. Awareness about Dynamic pricing has a positive influence on the motivation to display a strategic purchase behavior.

H2a. Awareness about Dynamic pricing has a positive influence on the Intentions to display a strategic purchase behaviour.

$\mathrm{H} 2 \mathrm{~b}$. Awareness about Dynamic pricing has a positive influence on the overall purchase satisfaction

People always have the tendency to emulate the behaviour of others. This is commonly acknowledged as the 'Herd behaviour' (Chen, 2008). The existence of information asymmetry and uncertainty in the online environment has resulted in the tendency of people to mimic other peoples' behaviour and integrate the information received in their decision making process (Brynjolfsson \& Smith, 2000; Chen, 2008). People who buy online tend to believe the opinion of other people; for example, online reviews, ratings, word of mouth etc. and their purchase decisions largely depend on the information received. Individuals use the information so received to minimise risks and maximise utility gained. This is more of a psychological phenomenon which make people believe in what most others believe irrespective of the truth and also make 
them think that other people possess better information than they themselves (Deutsch \& Gerard, 1995; Bonabeau, 2004). Given this information asymmetry and the presence of more noise buyers and information seekers than informed buyers in the online environment, there are chances for a consumer to get influenced by other people, especially friends and family who already exhibit strategic purchase behaviour. This study examines the effect of social influence on the strategic purchase behaviour.

H3. Social influence has a positive association with the motivation to display a strategic purchase behaviour

H3a. Social influence has a positive association with the intentions to display a Strategic Purchase Behaviour.

H3b. Social influence has a positive association with the overall Purchase Satisfaction.

The modern world is witnessing a rapid change in the customer behaviour and expectations. With the advent of industry 4.0, they anticipate the sellers to deliver cutting edge features on shopping websites and quality services at cheaper prices (Sheth et al. 2012). The sellers in turn are trying to adapt to these changes as fast as possible to satisfy their customers and to maintain a competitive edge in the cut throat market situation (Pereira, de Fátima Salgueiro, \& Rita, 2017). One of the main hurdles in this regard is that the customer perception which motivates them to engage in a purchase process is not linear. Hernandez et al. (2010) states that the perceptions which persuade consumers to shop online for the first time are not the same as those which motivate the repurchase behaviour. The factors changes as a consumer's perception evolves from the past experience. Hence it is pivotal to figure out and characterise the online consumer behaviour which help the sellers to identify the needs of the consumers and satisfy them in a better way. By offering memorable and satisfactory shopping experience the seller can build and retain a loyal customer base (Khalifa \& Liu, 2007). This study proposes to analyse the influence of the consumer's shopping experience on their intentions to track prices in a dynamic pricing context.

H4. Shopping Experience has a positive influence on the motivation to display a strategic purchase behaviour

H4a. Shopping Experience has a positive influence on the intentions to display a strategic purchase behaviour.

H4b. Shopping Experience has a positive influence on the overall purchase satisfaction.

Dai (2010) observed that the consumers show a high tendency to take self protection measures once exposed to a price change of high magnitude and proximity. Xia et al (2004) defines self protection intentions as consumers' intentions, to resort to measures which increases their personal benefits and reduce their perceived monetary disadvantage when a price is perceived as unfair. Dai (2010) further explains that consumers tend to resort to self protection measures when they perceive the difference in price or the magnitude of price changes is less fair. Deciding to take self protection measures imply that the consumers are not intending to purchase again from the same seller meaning that they are offended by the pricing strategy and not interested in taking advantage of it. This study verify how the self protection intentions are related to the strategic purchase behaviour and more importantly to the purchase satisfaction of the consumers.

H5. Self Protection Measures negatively influence the motivation to display a strategic purchase behaviour

H5a. Self Protection Measures negatively influence the intentions to display a strategic purchase behaviour.

H5b. Self Protection Measures negatively influence the overall purchase satisfaction.

The study also hypothesize that the purchase satisfaction influences the intentions of consumers to exhibit a strategic purchase behaviour. Purchase Satisfaction plays a key role in the repurchase intentions of 
consumers (Dai, 2010). In the context of dynamic pricing, this study analyses whether purchase satisfaction drives consumers to make repurchases by tracking the prices and waiting for price markdowns.

H6. Purchase Satisfaction has a negative influence on the intentions to display a strategic purchase behaviour.

Finally, the relationship between the intentions and actual decisions are analysed. Venkatesh et al (2003) states that behavioural intentions may not always get actualised. Here, the intentions to display a strategic purchase behaviour does not necessarily mean the respondents' actual desire to exhibit a strategic purchase behaviour. Hence we hypohesize;

H7. Intentions to display a strategic purchase behaviour has a positive influence on the actual strategic purchase behaviour.

\section{METHODOLOGY}

All constructs used in the study were adopted from previous studies. The constructs were measured using a 5-point Likert Scale of 1 - Strongly disagree and 5 - Strongly agree. The questionnaire consists of multiple items adapted from previous literature and some were tweaked to be consistent with the objectives and research setting.

The dependent variables in the study are Strategic Purchase Behaviour, Intentions to display a Strategic Purchase Behaviour and Purchase Satisfaction. The independent variables are Fair Price Perception, Social Influence, Awareness about Dynamic Pricing, Self Protection Measures and Shopping Experience. The constructs Social Influence and Intentions to display Strategic Purchase Behaviour, adapted from Venkatesh et al., (2003) were modified to fit the purpose of the research context.

Some of the items were reversely coded to ensure that the respondents are paying full attention to the long questionnaire.

All the constructs with respective items are given in Table 2 .

Table 2

Items used in the questionnaire

\begin{tabular}{|c|c|c|c|}
\hline Constructs & Items & Measurement & $\begin{array}{l}\text { Adapted } \\
\text { From }\end{array}$ \\
\hline $\begin{array}{l}\text { Fair Price } \\
\text { Perceptions } \\
\text { (FP) }\end{array}$ & $\begin{array}{l}\text { FP1 } \\
\text { FP2 } \\
\text { FP3 } \\
\text { FP4 } \\
\text { FP5 } \\
\text { FP6 }\end{array}$ & $\begin{array}{l}\text { The price I paid was fair. } \\
\text { The price I paid was justified. } \\
\text { The price I paid was honest. } \\
\text { The price I paid was unfair*. } \\
\text { The price I paid was questionable*. } \\
\text { The price I paid was a rip off* }\end{array}$ & $\begin{array}{c}\text { Darke \& } \\
\text { Dahl } \\
\text { (2003) }\end{array}$ \\
\hline $\begin{array}{c}\text { Awareness about } \\
\text { Dynamic Pricing } \\
\text { (DP) }\end{array}$ & $\begin{array}{l}\text { DP1 } \\
\text { DP2 } \\
\text { DP3 }\end{array}$ & $\begin{array}{l}\text { I am aware that the shopping websites collect personal } \\
\text { information through browser cookies* } \\
\text { I am aware that the shopping websites use the information } \\
\text { collected for personalised product recommendations and } \\
\text { advertisements* } \\
\text { I am aware that the shopping websites use the information } \\
\text { collected for making changes in the price of the products* }\end{array}$ & $\begin{array}{l}\text { Victor et } \\
\text { al., (2018) }\end{array}$ \\
\hline
\end{tabular}




\begin{tabular}{|c|c|c|c|}
\hline $\begin{array}{l}\text { Social } \\
\text { Influence } \\
\quad(\mathrm{SI})\end{array}$ & $\begin{array}{l}\text { SI1 } \\
\text { SI2 } \\
\text { SI3 }\end{array}$ & $\begin{array}{l}\text { I will make strategic buying plans (Tracking product prices } \\
\text { before purchase) if people around me are doing so } \\
\text { I will make strategic buying plans (Tracking product prices } \\
\text { before purchase) if my friends and family want me to do so } \\
\text { I will make strategic plans (Tracking product prices before } \\
\text { purchase) if people who influence me ask me to do so }\end{array}$ & $\begin{array}{l}\text { Venkatesh } \\
\text { et al., } 2012\end{array}$ \\
\hline $\begin{array}{l}\text { Shopping } \\
\text { Experience } \\
\text { (SE) }\end{array}$ & $\begin{array}{l}\text { SE1 } \\
\text { SE2 } \\
\text { SE3 } \\
\text { SE4 }\end{array}$ & $\begin{array}{l}\text { I am usually able to search useful information about the } \\
\text { products in the e shopping website } \\
\text { Shopping Websites can recommend substitute goods for } \\
\text { the product I wish to buy } \\
\text { The results provided by the shopping websites are quick } \\
\text { and fit to my needs } \\
\text { I believe product recommendation is very useful to me }\end{array}$ & $\begin{array}{c}\text { Tang and } \\
\text { Wu (2015) }\end{array}$ \\
\hline $\begin{array}{l}\text { Self Protection } \\
\text { Measures } \\
\text { (SP) }\end{array}$ & $\begin{array}{l}\text { SP1 } \\
\text { SP2 } \\
\text { SP3 } \\
\text { SP4 }\end{array}$ & $\begin{array}{l}\text { I will stop buying products from this retailer } \\
\text { I will buy fewer products from Amazon.com in the next } \\
\text { few years } \\
\text { I will buy more products from this retailer in the next few } \\
\text { years regardless of their pricing policy* } \\
\text { I will continue to buy the same product from this online } \\
\text { retailer if I need it in the future* }\end{array}$ & $\begin{array}{l}\text { Zeithaml } \\
\text { et al. } \\
\text { (1996) }\end{array}$ \\
\hline $\begin{array}{l}\text { Intentions to } \\
\text { display a strategic } \\
\text { Purchase } \\
\text { Behaviour } \\
\text { (ISPB) }\end{array}$ & $\begin{array}{l}\text { ISPB1 } \\
\text { ISPB2 } \\
\text { ISPB3 } \\
\text { ISPB4 }\end{array}$ & $\begin{array}{l}\text { In my opinion it is desirable to make strategic buying plans } \\
\text { rather than normal buying plans } \\
\text { I think it is good for me to switch from normal buying } \\
\text { plans to strategic buying plans } \\
\text { In my view, switiching from normal buying plan to } \\
\text { strategic byuing plan is a wise idea } \\
\text { I feel that switching from normal buying plan to strategic } \\
\text { buying plan is more profitable to me }\end{array}$ & $\begin{array}{l}\text { Venkatesh } \\
\text { et al., } 2012\end{array}$ \\
\hline $\begin{array}{c}\text { Strategic Purchase } \\
\text { Behaviour } \\
\text { (SPB) }\end{array}$ & $\begin{array}{l}\text { SPB1 } \\
\text { SPB2 } \\
\text { SPB3 } \\
\text { SPB4 }\end{array}$ & $\begin{array}{l}\text { In future, I will track the price of the products which I } \\
\text { intend to buy prior to purchase } \\
\text { I intend to use some software applications or browser } \\
\text { extensions to track the changes in the price of the product } \\
\text { I intend to consider the changing prices as an opportunity } \\
\text { to buy products at lower prices } \\
\text { I intend to motivate my friends \& family to track the prices } \\
\text { to avoid paying higher prices }\end{array}$ & $\begin{array}{l}\text { Victor et } \\
\text { al., (2018) }\end{array}$ \\
\hline $\begin{array}{l}\text { Purchase } \\
\text { Satisfaction } \\
\quad \text { (PS) }\end{array}$ & $\begin{array}{l}\text { PS1 } \\
\text { PS2 } \\
\text { PS3 } \\
\text { PS4 } \\
\text { PS5 }\end{array}$ & $\begin{array}{l}\text { I am satisfied with my purchase decision } \\
\text { My choice was wise } \\
\text { I think I selected the right retailer. } \\
\text { I am happy with my purchase decision } \\
\text { Overall, I am happy with my purchase experience }\end{array}$ & $\begin{array}{c}\text { Martin- } \\
\text { Consuegra } \\
\text { et } \\
\text { al. (2007) }\end{array}$ \\
\hline
\end{tabular}

Note: *Reverse Coded Items

\subsection{Data Analysis}

Partial Least Square based Structural Equation Modelling was chosen to test the research model (PLS SEM). The benefits of using PLS SEM is that it has fewer assumptions regarding the data distribution as compared to the covariance based (CB) SEM. PLS SEM can accommodate datasets without normal distribution and the results are robust even with smaller sample sizes (Chin et al. 2003). 
The research model was tested for convergent validity, discriminant validity and content validity and then a bootstrapping analysis (resampling $=4999$ ) was used to test the level of significance and $t$ values for all the paths. Bootstrapping is a commonly used analysis to test the quality of the structural model results in a PLS based SEM on a set of non-parametric evaluation criteria (Hair et al. 2016). ADANCO 2.0.1 and Gpower 3.1.9.2 were used to do all the analysis.

\subsection{Sample size and Data Collection Procedure}

The data was collected from the internet savvy millennials in Czestochowa region in Poland. A purposive and judgement sampling technique was used to choose the respondents for the study as followed in the previous studies related to this field (Le \& Liaw, 2017; Victor et al., 2018b). A preliminary screening was made to make sure that the respondents chosen had previous experiences with online purchases. Respondents without previous online purchase experience were not included in the study considering the difficulty to familiarise them with the basic concepts in online purchase as well as to avoid anomalies in the responses. A structured questionnaire was prepared both in Polish and English for the convenience of the respondents. The respondents were grouped into batches and the questionnaires were administered to the respondents in the computer labs of Czestochowa University of Technology.

In order to make sure that the respondents get a real time personal experience of the Dynamic pricing, a hypothetical scenario was developed and was explained to the respondents. Based on the personal experience with the scenario, they were asked to rate their reactions against the items given in the questionnaire. The items in the questionnaire is given in Table 2. Out of the 195 responses received, upon screening, 9 were removed for inserting inconsistent and conflicting inputs. Rest of the responses were used for the analysis. The sample adequacy requirement was tested using the Gpower software and confirmed that the sample size chosen was sufficient for the PLS based Structural Equation Modelling.

Table 3

Demographic features of the respondents

\begin{tabular}{|l|l|c|c|}
\hline Demographics & & Frequency & Percentage \\
\hline Gender & Male & 85 & $45.69 \%$ \\
\hline & Female & 101 & $54.30 \%$ \\
\hline Age & 15 to 25 & 147 & $79.03 \%$ \\
\hline & 26 to 35 & 30 & $16.12 \%$ \\
\hline & 36 and above & 9 & $4.73 \%$ \\
Average Time & Less than 1 hour & 62 & $33.33 \%$ \\
(Daily) & 1-2 Hours & 107 & $57.52 \%$ \\
\hline \multirow{2}{*}{$\begin{array}{l}\text { Usage Frequency in Online } \\
\text { Purchases }\end{array}$} & 3-4 Hours & 11 & $5.91 \%$ \\
& 5 Hours and Above & 6 & $3.22 \%$ \\
\hline & More than 10 times a year & 31 & $16.66 \%$ \\
& Less than 3 times a year & 40 & $61.82 \%$ \\
\hline
\end{tabular}

Table 3 shows the demographic profile of the respondents. Most of the respondents were females comprising $54.30 \%$ of the total respondents and males constituted the rest i.e. $45.69 \%$. Majority of the 
respondents are young population in the age group of $15-25$ comprising $79.03 \%$ of the total respondents. The age group 26-35 consisted of $16.12 \%$ and the age group 36 and above comprised $4.73 \%$ of the total respondents respectively. Most of the respondents i.e. around $57.52 \%$ spend $1-2$ hours on internet daily. Around $33.33 \%$ spend less than one hour daily and those who spend 3-4 hours, 5 hours and above daily comprise $5.91 \%$ and $3.22 \%$ of the total respondents respectively. On average, around $61.82 \%$ respondents buy $5-10$ products online a year. $21.50 \%$ make less than 3 purchases every year and $16.66 \%$ buy more than 10 times a year.

Table 4

Assessment of the Measurement Model

\begin{tabular}{|l|c|c|c|c|c|}
\hline \multicolumn{1}{|c|}{ Constructs } & $\begin{array}{c}\text { Measurement } \\
\text { Items }\end{array}$ & $\begin{array}{c}\text { Loading } \\
\text { Range }\end{array}$ & $\begin{array}{c}\text { Average } \\
\text { Composite } \\
\text { Reliability }\end{array}$ & $\begin{array}{c}\text { Variance } \\
\text { Extracted } \\
\text { (AVE) }\end{array}$ & $\begin{array}{c}\text { Cronbach`s } \\
\text { Alpha }\end{array}$ \\
\hline $\begin{array}{l}\text { Shopping } \\
\text { Experience }\end{array}$ & SE1,SE2,SE3,SE4 & $\begin{array}{c}0.5876- \\
0.8117\end{array}$ & 0.7608 & 0.5112 & 0.6851 \\
\hline $\begin{array}{l}\text { Awareness About } \\
\text { Dynamic Pricing }\end{array}$ & DP1,DP2,DP3 & $\begin{array}{c}0.7026- \\
0.8893\end{array}$ & 0.8479 & 0.6534 & 0.7315 \\
\hline $\begin{array}{l}\text { Fair } \\
\text { Price Perception }\end{array}$ & $\begin{array}{c}\text { FP1,FP2,FP3,FP4, } \\
\text { FP5,FP6 }\end{array}$ & $\begin{array}{c}0.7036- \\
0.8534\end{array}$ & 0.9022 & 0.6211 & 0.8863 \\
\hline $\begin{array}{l}\text { Purchase } \\
\text { Satisfaction }\end{array}$ & $\begin{array}{c}\text { PS1,PS2,PS3,PS4, } \\
\text { PS5 }\end{array}$ & $\begin{array}{c}0.8466- \\
0.9212\end{array}$ & 0.9380 & 0.7520 & 0.9174 \\
\hline $\begin{array}{l}\text { Intentions to } \\
\text { display Strategic } \\
\text { Purchase } \\
\text { Behaviour }\end{array}$ & $\begin{array}{c}\text { ISPB1,ISPB2,ISPB3, } \\
\text { ISPB4 }\end{array}$ & $\begin{array}{c}0.7158- \\
0.8545\end{array}$ & 0.8494 & 0.5861 & 0.7678 \\
\hline $\begin{array}{l}\text { Strategic Purchase } \\
\text { Behaviour }\end{array}$ & SPB1,SPB2,SPB3, & $\begin{array}{c}0.7275- \\
0.8549\end{array}$ & 0.8704 & 0.6279 & 0.8004 \\
\hline $\begin{array}{l}\text { Social } \\
\text { Influence }\end{array}$ & SI1,S12,S13 & $\begin{array}{c}0.7862- \\
0.8340\end{array}$ & 0.8554 & 0.6648 & 0.7504 \\
\hline $\begin{array}{l}\text { Self Protection } \\
\text { Intentions }\end{array}$ & SP3,SP4 & $\begin{array}{c}0.7910, \\
0.8867\end{array}$ & 0.8268 & 0.7059 & 0.7048 \\
\hline
\end{tabular}

The measurement model was assessed for content validity, convergent validity and discriminant validity. Factor Loadings, Average Variance Extracted (AVE) and Composite Reliability were examined for this purpose as recommended by Hair et al. (2016). Construct Validity implies how well the results obtained fit the theories around which the test is designed (Sekaran \& Bougie, 2010).

Hair et al, 2016 states that factor loadings in the range of 0.4 to 0.7 although considered weak should be examined carefully before removal to see how they impact the Composite Reliability values to confirm content validity. The items SP1 and SP2 were eliminated as the factor loadings were below 0.50 . For satisfying the convergent validity criterion, AVE scores of each construct is required to be above 0.50 (Hair et al., 2016), which means that they explain atleast half of the variance in its indicators. Composite Reliability above 0.7 and factor loadings above 0.5 are also required to prove convergent validity (Bagozzi \& Yi, 1988; Fornell \& Larcker, 1981). The results as per Table 4 shows that AVE scores, Composite Reliability values and factor loadings meet the criteria for confirming convergent validity of the proposed model. 
Discriminant Validity

\begin{tabular}{|c|c|c|c|c|c|c|c|c|}
\hline Constructs & SE & DP & FP & PS & SPB & ISPB & SI & SP \\
\hline SE & $\mathbf{0 . 4 6 0 2}$ & & & & & & & \\
\hline DP & 0.0385 & $\mathbf{0 . 6 5 3 4}$ & & & & & & \\
\hline FP & 0.0450 & 0.0064 & $\mathbf{0 . 6 2 1 1}$ & & & & & \\
\hline PS & 0.0684 & 0.0252 & 0.6171 & $\mathbf{0 . 7 5 2 0}$ & & & & \\
\hline SPB & 0.0673 & 0.0869 & 0.0630 & 0.0064 & $\mathbf{0 . 5 8 6 1}$ & & & \\
\hline ISPB & 0.0133 & 0.0915 & 0.0330 & 0.0535 & 0.0644 & $\mathbf{0 . 6 2 7 9}$ & & \\
\hline SI & 0.0752 & 0.0511 & 0.0004 & 0.0009 & 0.1664 & 0.1719 & $\mathbf{0 . 6 6 4 8}$ & \\
\hline SP & 0.0023 & 0.0000 & 0.1848 & 0.2884 & 0.0245 & 0.1108 & 0.0039 & $\mathbf{0 . 7 0 5 9}$ \\
\hline
\end{tabular}

Note: AVE given diagonally in boldface

The Fornell and Larcker criterion was used to assess the discriminant validity of the proposed model. Low correlations among the measures of constructs and the measures of interest indicate discriminant validity (Fornell \& Larcker, 1981). To display adequate discriminant validity, the square root of AVE scores should be higher than the correlation among them and all other constructs. From Table 5, it is evident that the AVE given diagonally in boldface are higher than that of other values which confirms the discriminant validity of the proposed model.

\subsection{Structural Model}

The structural model analysis was conducted based on the hypotheses. Other possible relationships between the constructs as derived from the literature review were also explored. Figure 2 illustrates the path coefficients (Beta Value) and their significance in the structural model and the coefficient of determination (R2). All Variance Inflation Factor (VIF) values of the independent variables were below the threshold level of 3, hence the chances of multicollinearity can be ruled out (O'Brien, 2007). The results show that the independent variables are able to explain a considerable percentage of variance in the dependent variables.

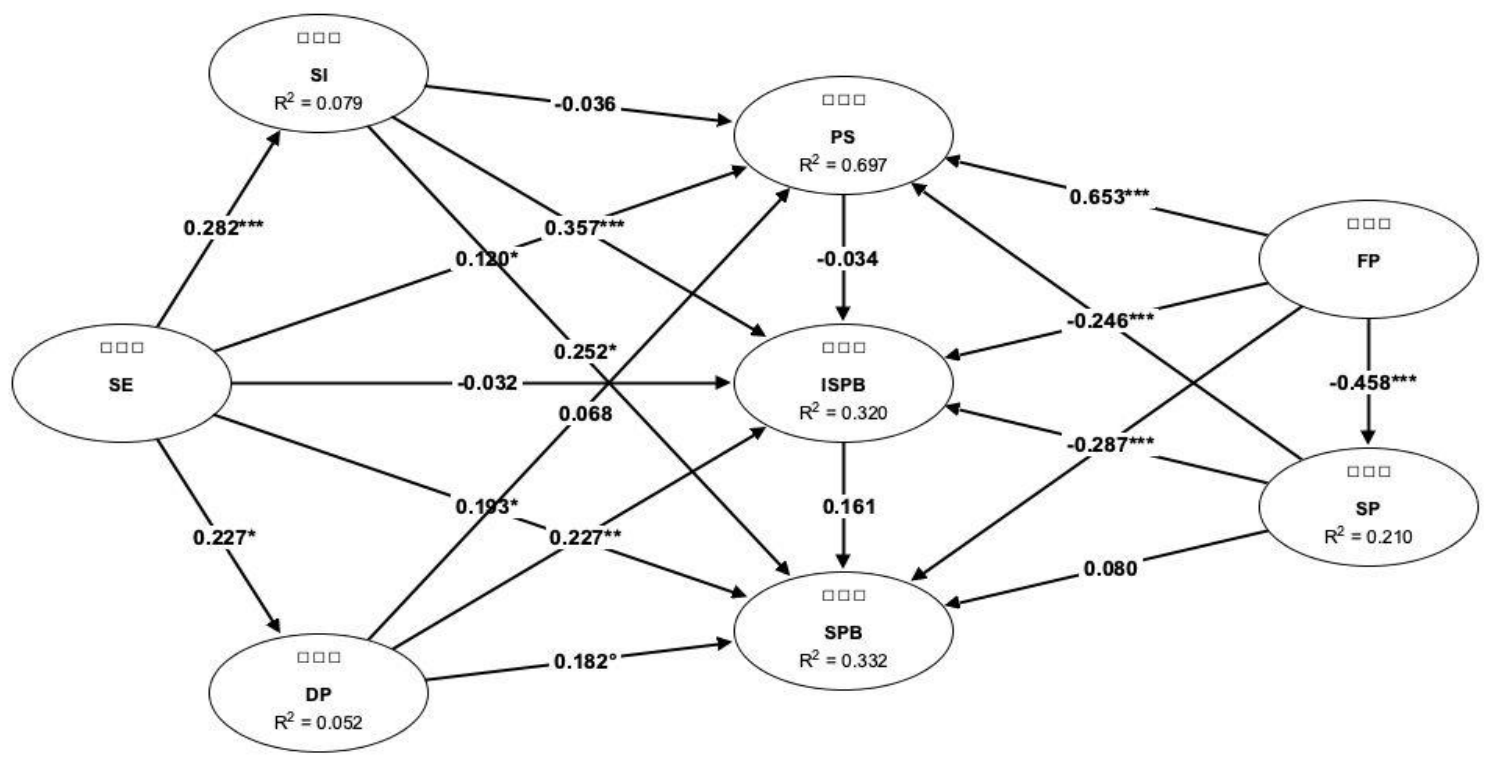

Figure 2. Structural model with Beta Values 
Chin (1998) categorised the R Squared values for endogenous latent variables as 0.67 (Substantial), 0.33 (Moderate) and 0.19 (Weak) in PLS path models. The model depicts that around 69\% of the variance in Purchase Satisfaction was explained by the independent variables. The independent variables also explain around 32 and $33 \%$ of the variance in ISPB and SPB respectively, which is a promising sign for future research in the field. Considering the novelty of the research field and the dearth of studies in the area, these results are of substantial importance to the E-Commerce companies employing dynamic pricing techniques. The hypotheses test results along with the significance of other relationships explored are given in detail in Table 6.

Table 6

Hypotheses Testing

\begin{tabular}{|c|c|c|c|c|c|c|}
\hline \multirow[b]{2}{*}{ Effect } & \multirow[b]{2}{*}{$\begin{array}{c}\text { Original } \\
\text { coefficient }\end{array}$} & \multicolumn{5}{|c|}{ Standard bootstrap results } \\
\hline & & $\begin{array}{l}\text { Mean } \\
\text { value }\end{array}$ & $\begin{array}{l}\text { Standard } \\
\text { error }\end{array}$ & t-value & $\begin{array}{l}\text { p-value (2- } \\
\text { sided) }\end{array}$ & $\begin{array}{l}\text { p-value (1- } \\
\text { sided) }\end{array}$ \\
\hline SE -> DP & 0.2273 & 0.2537 & 0.1060 & 2.1440 & 0.0321 & 0.0160 \\
\hline SE -> PS & 0.1203 & 0.1175 & 0.0585 & 2.0580 & 0.0396 & 0.0198 \\
\hline SE -> SPB & 0.1934 & 0.1993 & 0.0909 & 2.1290 & 0.0333 & 0.0166 \\
\hline SE -> ISPB & -0.0320 & -0.0295 & 0.0981 & $\begin{array}{l}-0.3263 \\
\end{array}$ & 0.7442 & 0.3721 \\
\hline SE -> SI & 0.2817 & 0.3028 & 0.0779 & 3.6163 & 0.0003 & 0.0002 \\
\hline SI -> PS & -0.0362 & -0.0339 & 0.0604 & -0.5988 & 0.5493 & 0.2747 \\
\hline SI -> SPB & 0.2518 & 0.2490 & 0.1016 & 2.4786 & 0.0132 & 0.0066 \\
\hline SI -> ISPB & 0.3567 & 0.3598 & 0.0866 & 4.1200 & 0.0000 & 0.0000 \\
\hline FP -> PS & 0.6529 & 0.6550 & 0.0487 & 13.4160 & 0.0000 & 0.0000 \\
\hline FP -> SPB & -0.2990 & -0.2938 & 0.1050 & -2.8483 & 0.0044 & 0.0022 \\
\hline FP -> ISPB & 0.0929 & 0.0904 & 0.1430 & 0.6494 & 0.5161 & 0.2581 \\
\hline FP -> SP & -0.4579 & -0.4630 & 0.0879 & -5.2120 & 0.0000 & 0.0000 \\
\hline PS -> ISPB & -0.0338 & -0.0340 & 0.1308 & -0.2586 & 0.7960 & 0.3980 \\
\hline ISPB -> SPB & 0.1606 & 0.1642 & 0.1082 & 1.4843 & 0.1378 & 0.0689 \\
\hline DP -> PS & 0.0685 & 0.0627 & 0.0623 & 1.0987 & 0.2720 & 0.1360 \\
\hline DP -> SPB & 0.1822 & 0.1822 & 0.0992 & 1.8370 & 0.0663 & 0.0331 \\
\hline DP -> ISPB & 0.2266 & 0.2370 & 0.0802 & 2.8250 & 0.0047 & 0.0024 \\
\hline SP $->$ PS & -0.2459 & -0.2425 & 0.0605 & -4.0645 & 0.0000 & 0.0000 \\
\hline SP -> SPB & 0.0799 & 0.0821 & 0.0967 & 0.8269 & 0.4083 & 0.2042 \\
\hline SP -> ISPB & -0.2867 & -0.2820 & 0.0782 & -3.6651 & 0.0002 & 0.0001 \\
\hline
\end{tabular}

\section{DISCUSSION}

The bootstrapping results given in Table 6 show that the construct shopping experience has a positive influence on purchase satisfaction and strategic purchase behaviour. This implies that the purchase satisfaction of consumers increases with useful and relevant product recommendations and a memorable shopping experience. It can also motivate the consumer to display a strategic purchase behaviour as there is a high probability that shopping experience can give them an idea on the price changes of a product. We thus confirm that the hypotheses $\mathrm{H} 4$ and $\mathrm{H} 4 \mathrm{~b}$ are supported. The Hypothesis $4 \mathrm{a}$ does not give a significant result and so we assume that shopping experience and intentions to display strategic purchase behaviour are not related to each other. It could also be seen from the results that shopping experience is positively related to awareness about dynamic pricing which means that the vivid experiences consumers gain every time they make a purchase lead to a better understanding of the pricing strategy of the sellers. This result is also concurred by a similar previous study by Victor et al., (2018b).

There is also a positive significant correlation between awareness about dynamic pricing and the probability to demonstrate a strategic purchase behaviour. This relationship is obvious, as consumers 
become more knowledgeable of the pricing strategy, they try to take advantage of it by delaying their purchases for future price markdowns. Shopping experience also has a direct relationship with social influence. As consumers get more experiences with a particular shopping website, it is highly likely that they would talk about it to their family and friends. The construct social influence has a positive and significant relationship with both the intentions and actual desire to display a strategic purchase behaviour. This alludes that friends and family can influence a consumer to track the prices of products which he/she would like to purchase and take advantage of the pricing strategy. Thus, we confirm that the hypotheses $\mathrm{H} 3$ and $\mathrm{H} 3 \mathrm{a}$ are supported. However, hypothesis H3b does not show a significant result implying that social influence and purchase satisfaction are not related.

Fair price perception of the consumer has a direct and very significant relationship with the purchase satisfaction. As the fair price perception of consumers get better, their purchase satisfaction also increases. This also imply that offering a reasonable price, which is in line with the customers willingness to pay will improve their purchase satisfaction. The results further depict that the fair price perception of a consumer is inversely related to the strategic purchase behaviour. This clearly points out that consumers tend to display a strategic purchase behaviour when their price perceptions do not match with that of the prices offered by the seller. Thus, it is very important for the sellers to figure out the range of fair price perceptions of consumers and set prices accordingly. This allows us to confirm that hypotheses $\mathrm{H} 1$ and $\mathrm{H} 1 \mathrm{~b}$ are supported. From the results, it can be also seen that fair price perception is not related with the intentions to display strategic purchase behaviour hence the hypothesis $\mathrm{H1}$ a is not proven. The results also show that fair price perception and self-protection intentions have an inverse relationship. This means that consumers can also resort to several measures for self-protection in their prospective purchase decisions if they have had a negative experience with dynamic pricing.

The results show that the awareness about dynamic pricing motivates the consumer to display intentions to exhibit strategic purchase behaviour. Once a consumer becomes aware of the pricing strategy, he/she is expected to take maximum advantage of it. However, it is further implied that the awareness about dynamic pricing does not necessarily lead to a strategic purchase behaviour (significant only on one sided $\mathrm{p}$ value) and purchase satisfaction (Not significant). Hence, we accept only hypothesis H2. Hypotheses H2a and $\mathrm{H} 2 \mathrm{~b}$ do not give a significant result implying that the constructs are not related. The construct selfprotection measures is inversely related to the purchase satisfaction and to the intentions to display a strategic purchase behaviour which means that as consumers resort to self-protection measures due to the extreme dynamic pricing strategy, it negatively influences their purchase satisfaction and the intentions to display a strategic purchase behaviour. The hypotheses $\mathrm{H} 5$ and $\mathrm{H} 5 \mathrm{~b}$ are therefore supported. The hypothesis H5a does not provide a significant result. From the results, it could be seen that purchase satisfaction does not have a significant influence on the intentions to display a strategic purchase behaviour and the intentions do not lead to the exhibition of an actual strategic purchase behaviour.

It is quite interesting to note the similarities and the differences in results with the previous researches (Victor et al., 2018a, Victor et al., 2018b) that was carried out in another fast growing E-Commerce market i.e. India. The previous studies also identified that the Fair Price Perception, Shopping Experience and Awareness About Dynamic Pricing as important variables which influenced the Strategic Purchase Decisions. However, the Fair Price Perceptions was positively correlated to the strategic purchase decision which implied that the consumers were ready to take advantage of the pricing strategy irrespective of their price perceptions. This also points out an important implication that the price perceptions of Polish consumers are more sensitive than that of the Indian consumers. This result could be attributed to the continuous exposure of Indian consumers to the extreme price volatility in E-Commerce employed by Amazon.in and other e-tailers which has conditioned them to perceive price fluctuations as normal. 


\section{CONCLUSION AND FUTURE RESEARCH DIRECTION}

This study concludes that the e-tailers employing discriminatory pricing strategies like dynamic pricing should take into account the fair price perceptions of the consumers which is found as the most significant factor that drive the consumers to make strategic buying decisions. The price perception of consumers is very sensitive to the magnitude and proximity of price fluctuations. It is therefore pivotal that the sellers should give prime importance to the consumer fair price perceptions while deciding the range of variation. The study also throws light on the fact that social influence is a major factor which lead the consumers to manifest a strategic purchase behaviour. Sellers should be mindful that even a single consumer who is aware of the pricing strategy can spread the word and persuade many others to display a strategic purchase behaviour which would hurt the profitability of the firm in the long run. Being aware of the price strategy can also influence the decision to exhibit a strategic purchase behaviour. A consumer who gets to know about the pricing strategy will wait for price markdowns and make the purchase once the online price matches his price perceptions. Again, this can be avoided by offering prices which are fair according to the consumers rather than employing an extremely fluctuating prices approach which also helps maintain a loyal customer base. On a positive note, prices could be allowed to fluctuate in a range which does not hurt a consumer's fair price perceptions. In that case, the consumer does not have a logical reason to display a strategic purchase behaviour which is not worth the search cost needed to be incurred to track prices before making a purchase decision. The purchase satisfaction of the consumers could be improved by offering fair prices for products and memorable shopping experiences. The sellers should make the shopping websites more resourceful and easier to navigate with more relevant product recommendations which is plausible to the consumers.

The research mainly focused on the consumer perceptions towards dynamic pricing in the Polish online retail context hence the results are better suited to the Polish E-Commerce sector. Similar researches can be carried out in other countries to replicate the results of this study. Although the sample size was found acceptable for this study, a larger sample size could be used in future studies involving respondents from different age groups. It is also recommended to include other factors such as consumer loyalty, trust, privacy concerns etc. which could influence the consumer desire to exhibit a strategic purchase behaviour to extend the model formulated in this study.

\section{REFERENCES}

Adams, J. S. (1965). Inequity in social exchange. Advances in Experimental Social Psychology, 2(1), 267-299.

Ajzen, I. (1991). The theory of planned behavior. Organizational Behavior and Human Decision Processes, 50(2), $179-211$.

Andreff, W., \& Szymanski, S. (Eds.). (2006). Handbook on the Economics of Sport. Edward Elgar Publishing.

Arvola, A., Vassallo, M., Dean, M., Lampila, P., Saba, A., Lähteenmäki, L., \& Shepherd, R. (2008). Predicting intentions to purchase organic food: The role of affective and moral attitudes in the Theory of Planned Behaviour. Appetite, 50(2-3), 443-454.

Aviv, Y., \& Pazgal, A. (2008). Optimal pricing of seasonal products in the presence of forward-looking consumers. Manufacturing \& Service Operations Management, 10(3), 339-359.

Bandura, A. (1980). Gauging the relationship between self-efficacy judgment and action. Cognitive therapy and research, $4(2), 263-268$.

Besbes, O., \& Lobel, I. (2015). Intertemporal price discrimination: Structure and computation of optimal policies. Management Science, 61(1), 92-110.

Bolton, L. E., Warlop, L., \& Alba, J. W. (2003). Consumer perceptions of price (un) fairness. Journal of consumer research, $29(4), 474-491$.

Bonabeau, E. (2004). The perils of the imitation age. Harvard business review, 82(6), 45-54. 
Bredzel-Skowera, K., \& Turek, T. (2015). The prospects of E-commerce in Poland. Procedia Computer Science, 65, 11141123.

Brynjolfsson, E., \& Smith, M. D. (2000). Frictionless commerce? A comparison of Internet and conventional retailers. Management science, 46(4), 563-585.

Cachon, G. P., \& Feldman, P. (2015). Price commitments with strategic consumers: Why it can be optimal to discount more frequently... than optimal. Manufacturing \& Service Operations Management, 17(3), 399-410.

Chatzidakis, A., Hibbert, S., \& Smith, A. P. (2007). Why people don't take their concerns about fair trade to the supermarket: The role of neutralisation. Journal of business ethics, 74(1), 89-100.

Chin, W. W. (1998). The partial least squares approach to structural equation modeling. Modern methods for business research, 295(2), 295-336.

Cross, R. (1997) Revenue Management: Hard-Core Tactics for Market Domination. New York, NY: Broadway Books.

Dai, B. (2010). The impact of perceived price fairness of dynamic pricing on customer satisfaction and behavioral intentions: The moderating role of customer loyalty (Doctoral dissertation).

Darke, P. R., \& Dahl, D. W. (2003). Fairness and discounts: The subjective value of a bargain. Journal of Consumer Psychology, 13 (3), 328-338.

Deutsch, M., \& Gerard, H. B. (1955). A study of normative and informational social influences upon individual judgment. The journal of abnormal and social psychology, 51(3), 629.

Dinev, T., \& Hart, P. (2006). An extended privacy calculus model for e-commerce transactions. Information systems research, 17(1), 61-80.

Dong, L., Kouvelis, P., \& Tian, Z. (2009). Dynamic pricing and inventory control of substitute products. Manufacturing \& Service Operations Management, 11(2), 317-339.

European Commission (2018) Consumer market study on online market segmentation through personalised pricing/offers in the European Union. Retrieved March 04, 2019, from https://ec.europa.eu/info/sites/info/files/aid development cooperation fundamental rights/aid and dev elopment by topic/documents/synthesis report online personalisation study final 0.pdf

Export. Gov (2018)Poland e-Commerce, Retrieved on 15 march 2019, from https://www.export.gov/article?id=Poland-eCommerce.

Gönsch, J., Klein, R., \& Steinhardt, C. (2009). Dynamic pricing-state-of-the-art. Journal of Business Administration, Supplement , $3,1-40$.

Greenstein-Messica, A., \& Rokach, L. (2018). Personal price aware multi-seller recommender system: Evidence from eBay. Knowledge-Based Systems, 150(1), 14-26.

Hair, J, F., Jr., G. T. M. Hult, C. Ringle., \& M. Sarstedt. (2016) A Primer on Partial Least Squares Structural Equation Modeling (PLS-SEM), 2nd ed. Thousand Oaks: Sage Publications.

Han, S., Fu, Y., Cao, B., \& Luo, Z. (2018). Pricing and bargaining strategy of e-retail under hybrid operational patterns. Annals of Operations Research, 270(1-2), 179-200.

Haws, K. L., \& Bearden, W. O. (2006). Dynamic pricing and consumer fairness perceptions. Journal of Consumer Research, 33(3), 304-311.

Hawthorne, J., \& Stanley, J. (2008). Knowledge and action. The Journal of Philosophy, 105(10), 571-590.

Hernández, B., Jiménez, J., \& Martín, M. J. (2010). Customer behavior in electronic commerce: The moderating effect of e-purchasing experience. Journal of business research, 63(9-10), 964-971.Ecommerce Report Central and Eastern Europe (2018), Retrieved on 15 March 2019, from https://www.ecommerce-europe.eu/research/ecommerceeurope-reports https://www.statista.com/statistics/567523/predicted-internet-user-penetration-rate-in-poland/.

Kambil, A., Wilson, H.J, and Agrawal, V. (2002). Are you leaving money on the table?, The Journal of Business Strategy, 23(1), 40-43.

Keepa (2019) Retrieved, September 16, 2019, from https://keepa.com/\#!tracking .

Khalifa, M., \& Liu, V. (2007). Online consumer retention: contingent effects of online shopping habit and online shopping experience. European Journal of Information Systems, 16(6), 780-792.

Krugman, P. (2000). What price fairness?, The New York Times, 4, A35.

Le, T., \& Liaw, S. Y. (2017). Effects of pros and cons of applying big data analytics to consumers' responses in an ecommerce context. Sustainability, 9(5), 798. 
Liu, Q., \& Van Ryzin, G. J. (2008). Strategic capacity rationing to induce early purchases. Management Science, 54(6), 1115-1131.

Lovelock, C. H. (1984). Strategies for managing demand in capacity-constrained service organisations. The Service Industries Journal, 4(3), 12-30.

Martín-Consuegra, D., Molina, A., \& Esteban, Á. (2007). An integrated model of price, satisfaction and loyalty: an empirical analysis in the service sector. Journal of Product \& Brand Management, 16(7), 459-468.

Moore, R. C. (1981). Reasoning about knowledge and action. In Readings in Artificial Intelligence. Morgan Kaufmann.

O’brien, R. M. (2007). A caution regarding rules of thumb for variance inflation factors. Quality \& quantity, 41(5), 673690.

OECD (2018). Personalised Pricing in the Digital Era. Retrieved on 10 February 2019, from http://www.oecd.org/daf/competition/personalised-pricing-in-the-digital-era.html,

Oláh, J., Kitukutha, N., Haddad, H., Pakurár, M., Máté, D., \& Popp, J. (2018). Achieving sustainable e-Commerce in environmental, social and economic dimensions by taking possible trade-offs. Sustainability, 11(1), 1-22.

Omelchenko, E., Andreeva, Y., Arif, E., \& Polyakov, S. (2016). Where Do Time and all of the Money go? Consumer Strategies of Urban Youth in Modern Russia. Economics and Sociology, 9(4), 176-190. doi:10.14254/2071789X.2016/9-4/11

Ouellette, J. A., \& Wood, W. (1998). Habit and intention in everyday life: The multiple processes by which past behavior predicts future behavior. Psychological Bulletin, 124, 54-74.

Papanastasiou, Y., \& Savva, N. (2016). Dynamic pricing in the presence of social learning and strategic consumers. Management Science, 63(4), 919-939.

Pereira, H. G., de Fátima Salgueiro, M., \& Rita, P. (2017). Online determinants of e-customer satisfaction: application to website purchases in tourism. Service Business, 11(2), 375-403. https://doi.org/10.1007/s11628-016-0313-6

PK Kannan, P. K. K. (2001). Dynamic pricing on the Internet: Importance and implications for consumer behavior. International Journal of Electronic Commerce, 5(3), 63-83.

Sahay, A. (2007), How Dynamic Pricing Leads to Higher Profits. MIT Sloan Management Review. 48(4), 53-60.

Schlosser, R., \& Boissier, M. (2018). Dealing with the dimensionality curse in dynamic pricing competition: Using frequent repricing to compensate imperfect market anticipations. Computers \& Operations Research, 100(1), 2642.

Sekaran, U., \& R. Bougie (2010) Research Method for Business, 5th ed. New York: John Wiley and Sons.

Shaw, D., \& Shiu, E. (2002). An assessment of ethical obligation and self-identity in ethical consumer decision-making: a structural equation modelling approach. International Journal of Consumer Studies, 26(4), 286-293.

Sheth, J. N., Parvatiyar, A., \& Sinha, M. (2012). The conceptual foundations of relationship marketing: Review and synthesis. Economic sociology_the european electronic newsletter, 13(3), 4-26

Shiller, B. R. (2013). First degree price discrimination using big data, Brandeis Univ., Department of Economics.

Slintak, K. (2019). A New Concept of Management. Montenegrin Journal of Economics, 15(1), 199-213.

Statista (2019) Forecast of the internet user penetration rate in Poland from 2017 to 2023, Retrieved on 15 March 2019, from,

Stefko, R., Dorcak, P., \& Pollák, F. (2011). Shopping on the Internet from the point of view of customers. Polish Journal of Management Studies, 4 (1), 214-222.

Tang, M., \& Wu, Z. (2015). Research on the mechanisms of big data on consumer behavior using the models of C2C e-commerce and countermeasures. African Journal of Business Management, 9(1), 18-34.

Tellis, G. J. (1986). Beyond the many faces of price: an integration of pricing strategies. Journal of marketing, 50(4), 146160.

Townley, C., Morrison, E., \& Yeung, K. (2017). Big data and personalized price discrimination in EU competition law. Yearbook of European Law, 36, 683-748.

Vdovtsova, S. (2008). Motivation mechanisms of youth behavior on Ukrainian labour market. Economics \& Sociology, 1(1), 104-109.

Venkatesh, V., Morris, M. G., Davis, G. B., \& Davis, F. D. (2003). User acceptance of information technology: Toward a unified view. MIS quarterly, 27(3), 425-478. 
Vermeir, I., \& Verbeke, W. (2008). Sustainable food consumption among you adults in Belgium: Theory of planned behaviour and the role of confidence and values. Ecological economics, 64(3), 542-553.

Victor, V., \& Bhaskar. M. (2017) Dynamic Pricing and the Economic Paradigm Shift-A Study Based on Consumer Behaviour in the E-commerce Sector. International Journal of Scientific and Research Publications, 7(1), 242-47.

Victor, V., Joy Thoppan, J., Jeyakumar Nathan, R., \& Farkas Maria, F. (2018a). Factors influencing consumer behavior and prospective purchase decisions in a dynamic pricing environment - An exploratory factor analysis approach. Social Sciences, 7(9), 153.

Victor, V., Nathan, R. J., Grabara, J., \& Fekete-Farkas, M. (2018b). Price tracking behaviour in Electronic Commerce and the moderating role of fair price perception. Polish Journal of Management Studies, 18(2), 375-387.

Vovk, I., \& Vovk, Y. (2017). Development of family leisure activities in the hotel and restaurant businesses: Psychological and pedagogical aspects of animation activity. Economics, Management and Sustainability, 2(1), 67-75.

Xia, L., Monroe, K. B., \& Cox, J. L. (2004). The price is unfair! A conceptual framework of price fairness perceptions. Journal of marketing, 68(4), 1-15.

$\mathrm{Xu}, \mathrm{H}$. (2018). To compete or to take over? An economic analysis of new sellers on e-commerce marketplaces. Information Systems and e-Business Management, 16(4), 817-829.

Yin, R., Aviv, Y., Pazgal, A., \& Tang, C. S. (2009). Optimal markdown pricing: Implications of inventory display formats in the presence of strategic customers. Management Science, 55(8), 1391-1408.ng

Zeithaml, V. A., Berry, L. L., \& Parasuraman, A. (1996). The behavioral consequences of service quality. Journal of marketing, 60(2), 31-46.

Zhidebekkyzy, A., Kupeshova, S., \& Yesmurzayeva, A. (2019). Project management in Nanotechnology: A systematic literature review. Montenegrin Journal of Economics, 15(3), 227-244. 